\title{
Molecular phylogenetics and character evolution of the "sacaca" clade: Novel relationships of Croton section Cleodora (Euphorbiaceae)
}

\author{
Maria Beatriz R. Caruzo ${ }^{\mathrm{a}, \mathrm{b}, *}$, Benjamin W. van Ee ${ }^{\mathrm{c}}$, Inês Cordeiro ${ }^{\mathrm{b}}$, Paul E. Berry ${ }^{\mathrm{d}}$, Ricarda Riina ${ }^{\mathrm{d}, \mathrm{e}}$ \\ a Departamento de Botânica, Instituto de Biociências, Universidade de São Paulo Cx. Postal 11461, 05422-970, São Paulo, SP, Brazil \\ ${ }^{\mathrm{b}}$ Instituto de Botânica, Secretaria do Meio Ambiente, Cx. Postal 3005, 01061-970, São Paulo, SP, Brazil \\ 'Black Hills State University Herbarium, 1200 University Street, Spearfish, SD 57799, USA \\ ${ }^{\mathrm{d}}$ University of Michigan Herbarium, 3600 Varsity Drive, Ann Arbor, MI 48109-2228, USA \\ e Real Jardín Botánico, CSIC, Plaza Murillo 2, Madrid 28014, Spain
}

\section{A R T I C L E I N F O}

\section{Article history:}

Received 12 April 2010

Revised 11 April 2011

Accepted 18 April 2011

Available online 29 April 2011

\section{Keywords:}

Neotropical Croton

Section Cleodora

Subsection Sphaerogyni

Subsection Spruceani

Croton cajucara

\begin{abstract}
A B S T R A C T
Phylogenetic relationships of Croton section Cleodora (Klotzsch) Baill. were evaluated using the nuclear ribosomal ITS and the chloroplast trnL-F and trnH-psbA regions. Our results show a strongly supported clade containing most previously recognized section Cleodora species, plus some other species morphologically similar to them. Two morphological synapomorphies that support section Cleodora as a clade include pistillate flowers in which the sepals overlap to some degree, and styles that are connate at the base to varying degrees. The evolution of vegetative and floral characters that have previously been relied on for taxonomic decisions within this group are evaluated in light of the phylogenetic hypotheses. Within section Cleodora there are two well-supported clades, which are proposed here as subsections (subsection Sphaerogyni and subsection Spruceani). The resulting phylogenetic hypothesis identifies the closest relatives of the medicinally important and essential oil-rich Croton cajucara Benth. as candidates for future screening in phytochemical and pharmacological studies.
\end{abstract}

두 2011 Elsevier Inc. All rights reserved.

\section{Introduction}

Croton L., the second largest genus of Euphorbiaceae, is an important pantropical lineage with several species that are employed in traditional medicine practices in Africa, Asia, and South America (Moreno et al., 2009; Salatino et al., 2007). The genus has over 1200 species (Govaerts et al., 2000), ranking it as the 11 th largest angiosperm genus (Frodin, 2004). It is found in tropical regions worldwide, although there are some representatives in subtropical and northern temperate areas as well. The Neotropics is the most species-rich region for the genus, with main centers of diversity in Brazil, the West Indies, and Mexico (Burger and Huft, 1995). Croton has great morphological diversity, ranging from herbs to shrubs to trees, rarely lianas, and it occupies a wide range of habitats. The genus is found in almost all types of vegetation, but most species grow in dry or open vegetation, and in disturbed sites.

The first attempts to recognize infrageneric groupings within Croton date back to Baillon $(1858,1864)$, and more recently Webster (1993) recognized 40 sections and five subsections within

\footnotetext{
* Corresponding author at: Instituto de Botânica, Secretaria do Meio Ambiente, Cx. Postal 3005, 01061-970, São Paulo, SP, Brazil.

E-mail addresses: mbrcaruzo@hotmail.com (Maria Beatriz R. Caruzo), bvanee@ uwalumni.com (B.W. van Ee), isandona@uol.com.br (I. Cordeiro), peberry@umich. edu (P.E. Berry), riina@umich.edu (R. Riina).
}

the genus. Berry et al. (2005) undertook the first molecular phylogenetic study of Croton and related groups. They showed that Croton was monophyletic once the former section Astraea (Klotzsch) Baill. was removed and restored to separate generic status. Since then, several other phylogenetic studies have contributed to building an infrageneric classification of Croton that reflects phylogenetic relationships (Riina et al., 2009, 2010; Van Ee and Berry, 2009, 2010, 2011; Van Ee et al., 2008, in press). Nonetheless, the basic relationships within many sections have yet to be explored.

One of the groups in need of critical revision is Croton section Cleodora (Klotzsch) Baill., which is concentrated in Brazil, but with a few members extending as far north as central Mexico. A species belonging to this section, Croton cajucara Benth., popularly known as "sacaca" (from the Tupi language, sake'ka, which means "witchcraft" or "spellcasting"; Le Cointe, 1934), has historically been used in the Amazon region to treat diarrhea, diabetes, liver and kidney problems, to lower cholesterol, and for weight loss (Salatino et al., 2007). Guided by the traditional ethnobotanical uses of $C$. cajucara, numerous researchers have explored the phytochemical and pharmacological properties of this species (Carvalho et al., 1996; Farias et al., 1997; Maciel et al., 1998a, 1998b; Souza-Brito et al., 1998; Grynberg et al., 1999; Lemos et al., 1999; Hiruma-Lima et al., 1999a; Maciel et al., 2000; Campos et al., 2002; Hiruma-Lima et al., 2002; Maciel et al., 2002; Grassi-Kassisse et al., 2003; Rosa et al., 2003; Alviano et al., 
2005; Brito et al., 2006; Santos et al., 2006; Souza et al., 2006; Perazzo et al., 2007). The effectiveness of $C$. cajucara at reducing lipid and glucose levels has been demonstrated in the laboratory by several authors (Farias et al., 1996, 1997; Costa et al., 1999; Grynberg et al., 1999; Hiruma-Lima et al., 1999b; Maciel et al., 2000; Silva et al., 2001a, 2001b). Croton cajucara has also been shown to contain high levels of linalool, an alcohol used in the perfume industry (Araújo et al., 1971), which has raised much interest in this species among researchers in recent years (Moreno et al., 2009). Although Müller (1873) implied a close relationship between C. cajucara, C. heterocalyx Baill., and C. sphaerogynus Baill. by placing them together in his key, we are aware of no other publication until Webster (1993) that suggests what the closest relatives of $C$. cajucara might be. All phytochemical and pharmacological investigations within section Cleodora had been confined to C. cajucara until Moreno et al. (2009), who tested C. heterocalyx based on the hypothesis of close relationship implied by the taxonomic treatment of Webster (1993), discovered that it also contains linalool and has antimicrobial properties. Moreno et al. (2009) found 17 chemical compounds in common between the essential oils of $C$. heterocalyx and those found in $C$. cajucara by Lopes et al. (2000). Herein we provide a more comprehensive hypothesis of the phylogenetic relationships of the species related to $C$. cajucara and $C$. heterocalyx, which may be useful for further bioprospecting in this group. We expect that most of the species of section Cleodora will be subjected to phytochemical assays in the coming years, and this information can then be overlaid onto the phylogeny to reconstruct patterns of chemical evolution in this group.

Croton section Cleodora was defined morphologically by Webster (1993) by the presence of appressed-stellate trichomes, petiolar glands, terminal inflorescences usually with bisexual cymules, staminate flowers with 15-20 stamens, and pistillate flowers with multifid styles and united and/or imbricate sepals. Webster (1993) placed the following species in the section: Croton cajucara Benth., C. calycularis Huber (=C. spruceanus Benth.), C. hemiargyreus Müll.Arg., C. heterocalyx Baill., C. hoffmannii Müll.Arg., C. maracayuensis Chodat \& Hassl. (=C. floribundus Spreng.), C. seputubensis Hoehne ( $=$ C. cajucara), and $C$. sphaerogynus Baill.

In a molecular phylogenetic analysis of relationships within Croton section Cyclostigma Griseb., Riina et al. (2009) recovered two species that were previously placed in that section, namely Croton organensis Baill. and C. warmingii Müll.Arg. (=C. rottlerifolius Baill.), emerging in a clade with C. cajucara and C. hoffmannii, both species traditionally placed in section Cleodora. This prompted us to increase our sampling beyond the traditional circumscription of section Cleodora by adding species such as $C$. organensis and $C$. rottlerifolius, as well as other taxa morphologically suggestive of the section. Given the extensive pharmacological interest in $C$. cajucara, we wish to identify the closest relatives of this medicinally important species to point out new candidate species for pharmacological screening. Within section Cleodora we also aim to use molecular methods to reconstruct the phylogenetic relationships of its members, introduce a phylogenetic classification, identify morphological synapomorphies and diagnostic characters, and investigate the evolution of floral characters.

\section{Materials and methods}

\subsection{Taxon sampling and DNA sequencing}

Species from section Cleodora sensu Webster (1993), and species with a similar morphology but of uncertain sectional placement, were included in our molecular sampling. A selection of taxa belonging to other sections and lineages of Croton were used to establish the limits of section Cleodora. We used two outgroup taxa, Astraea lobata (L.) Klotzsch and Brasiliocroton mamoninha Berry \& Cordeiro, following the findings of Berry et al. (2005).

DNA was extracted from silica-dried or herbarium tissue of single individuals using the DNeasy Plant Mini kit (Quiagen, Valencia, California) following the manufacturer's instructions. The nuclear ribosomal ITS (ITS1, 5.8s, and ITS2) and the chloroplast trnL intron and $t r n L-F$ intergenic spacer regions (hereafter collectively referred to as "trnL-F") were amplified and sequenced employing the same methods as described in Berry et al. (2005). These two loci have been used in all species level phylogenies of Croton to date (Berry et al., 2005; Van Ee et al., 2008; Cordeiro et al., 2008; Van Ee and Berry, 2009, 2010, 2011; Riina et al., 2009, 2010). We added the non-coding plastid trnH-psbA spacer region, which given its high sequence variability has been shown to be a good candidate for a DNA barcoding region (Kress et al., 2005; Lahaye et al., 2008). The $t r n H-p s b A$ region was amplified and sequenced using primers trnH ${ }^{\text {GUG }}$ (Tate and Simpson, 2003) and psbA (Sang et al., 1997).

Polymerase chain reaction (PCR) amplification of the $t r n H-p s b A$ marker was performed with $0.1 \mathrm{U}$ of HotStarTaq DNA Polymerase (Quiagen Inc., Valencia, California, USA), $1 \times$ PCR Buffer $(50 \mathrm{mM}$ $\mathrm{KCL}, 10 \mathrm{mM}$ Tris $\mathrm{HCl}$, ph 9), $200 \mu \mathrm{M}$ of each dNTP, $2.0 \mathrm{mM} \mathrm{MgCl}_{2}$, $0.4 \mu \mathrm{M}$ of each primer, and 25-90 ng of template DNA in a volume of $25 \mu \mathrm{L}$. The PCR profile consisted of an initial denaturing step at $95{ }^{\circ} \mathrm{C}$ for $15 \mathrm{~min}$, amplification proceeded at one cycle of $95^{\circ} \mathrm{C}$ for $1 \mathrm{~min}, 65^{\circ} \mathrm{C}$ for $1 \mathrm{~min}, 72^{\circ} \mathrm{C}$ for $1 \mathrm{~min}$; one cycle of $95^{\circ} \mathrm{C}$ for $1 \mathrm{~min}, 64^{\circ} \mathrm{C}$ for $1 \mathrm{~min}, 72^{\circ} \mathrm{C}$ for $1 \mathrm{~min} ; 1$ cycle of $95^{\circ} \mathrm{C}$ for $1 \mathrm{~min}$, $63^{\circ} \mathrm{C}$ for $1 \mathrm{~min}, 72^{\circ} \mathrm{C}$ for $1 \mathrm{~min}$; one cycle of $95^{\circ} \mathrm{C}$ for $1 \mathrm{~min}$, $62{ }^{\circ} \mathrm{C}$ for $1 \mathrm{~min}, 72^{\circ} \mathrm{C}$ for $1 \mathrm{~min}$; one cycle of $95^{\circ} \mathrm{C}$ for $1 \mathrm{~min}$, $60{ }^{\circ} \mathrm{C}$ for $1 \mathrm{~min}, 72^{\circ} \mathrm{C}$ for $1 \mathrm{~min}$; one cycle of $95^{\circ} \mathrm{C}$ for $1 \mathrm{~min}$, $57^{\circ} \mathrm{C}$ for $1 \mathrm{~min}, 72{ }^{\circ} \mathrm{C}$ for $1 \mathrm{~min}$; then followed by 19 cycles of $95^{\circ} \mathrm{C}$ for $1 \mathrm{~min}, 55^{\circ} \mathrm{C}$ for $1 \mathrm{~min}, 72^{\circ} \mathrm{C}$ for $1 \mathrm{~min}$, with a final 15 min extension at $72^{\circ} \mathrm{C}$. PCR products were cleaned using ExoSAP-IT (USB Corp., Cleveland, Ohio) following the manufacturer's protocol, and sequenced on $\mathrm{ABI} 3730$ sequencers at the University of Michigan DNA Sequencing Core. Sequences were edited and assembled using the Staden Package v. 2003.0b1 (Staden, 1996), and then aligned in Clustal X (Thompson et al., 1997). The programs BioEdit v. 7.0.0 (Hall, 1999) and MEGA4 (Tamura et al., 2007) were used to make manual adjustments to the alignment generated by Clustal X.

The combined data matrix consists of 42 accessions, and although $t r n H-p s b A$ was not sequenced for five species (C. hircinus Vent., C. hirtus L'Hér., C. megalodendron Müll.Arg., C. pallidulus Baill. and $C$. velutinus Baill.), they were included in the combined analysis with that portion coded as missing. A list of species sampled, localities, herbarium vouchers, and GenBank numbers for all sequences is provided in Appendix A. All trnH-psbA sequences are new, 20 of the $t r n L-F$ sequences are new, and 18 of the ITS sequences are new.

\subsection{Phylogenetic analyses}

Congruence between the nuclear and chloroplast loci, as well as between the two different chloroplast loci, was evaluated using the incongruence length difference (ILD) test (Farris et al., 1994) as implemented in PAUP* v. 4.0b10 (Swofford, 2002). The ILD test was conducted using 1000 partition homogeneity replicates of 10 random addition sequence replicates (RASR) each, tree-bisectionreconnection (TBR) branch-swapping, holding one tree at each step, nchuck $=100$, and excluding uninformative characters and taxa with missing data.

Maximum parsimony (MP) heuristic searches were performed in PAUP $^{*}$ with 1000 random taxon addition replicates using TBR branch-swapping. All characters were included in the analyses. Characters were equally weighted, and gaps were treated as missing data. MP bootstrap (BS) values for the combined and individual 
nuclear and chloroplast loci were estimated using 1000 bootstrap replicates of 100 RASR each, TBR, and nchuck $=100$.

Bayesian analyses were conducted in MrBayes v. 3.1.2 (Huelsenbeck and Ronquist, 2001). Bayesian posterior probabilities (PP) were calculated from two Markov chain Monte Carlo (MCMC) analyses, each consisting of four linked chains (heat $=0.02$ ), $1,000,000$ generations, and sampling every 50 generations. All characters were included in the analyses, and the data were divided into three partitions (ITS, trnL-F, and trnH-psbA) with MrBayes estimating the best model parameters for each partition independently. The burn-in period was estimated by visual examination of the likelihood-by-generation plot and, after removing the trees from the burn-in period, PP values were obtained by computing a majority rule consensus of the trees from both MCMC chains.

\subsection{Character state mapping}

Eight morphological characters were scored from fresh material and herbarium samples for the entire dataset (Table 1). Most of the selected characters have been used in previous systematic studies in Croton (Webster, 1993; Caruzo and Cordeiro, 2007; Lima and Pirani, 2008; Van Ee et al., 2008). To assess the patterns of evolution of these characters, we mapped them onto one of the most parsimonious trees obtained from the combined parsimony analysis. We reconstructed ancestral character states using parsimony as implemented in Mesquite v. 2.72 (Maddison and Maddison, 2009). All characters were treated as unordered.

\section{Results}

\subsection{Molecular data sets and congruence}

The aligned lengths of the three regions, as well as information regarding the variable and parsimony-informative characters, are given in Table 2. The nuclear ITS (Fig. 1) and trnL-F+trnH-psbA chloroplast (Fig. 2) phylogenies do not differ from each other, or from the results of the combined analysis (Fig. 3), in any strongly-supported way, with the exception that the chloroplast analyses recovered section Cyclostigma apart from section Adenophylli (formerly known as section Cascarilla), a result discussed in greater detail by Riina et al. (2009). This difference in topology is likely the reason that the ILD test rejects the hypothesis of no meaningful conflict between the nuclear and chloroplast data $(p=0.004)$. In contrast, the ILD test conducted between the two chloroplast regions (trnL-F and trnH-psbA) failed to reject the hypothesis of no meaningful conflict between them $(p=0.630)$. The phylogenetic relationships within section Cleodora inferred from the different molecular markers are very similar to each other. We therefore discuss the phylogenetic relationships among species of section Cleodora using the combined data phylogeny (Fig. 3), and refer to the contrasting results obtained from

Table 1

Morphological characters and coding information.

\begin{tabular}{ll}
\hline Character & Coding \\
\hline Trichomes & 0 = stellate, 1 = lepidote \\
Petiolar glands & $0=$ absent, 1 = present \\
Bisexual cymules & $0=$ absent, 1 = present \\
Connation of pistillate sepals & $0=$ united at the base, 1 = united half \\
& of their length, 2 = united almost to the apex \\
Pistillate flower aestivation & $0=$ valvate, $1=$ reduplicate-valvate, \\
& $2=$ imbricate, $3=$ quincuncial \\
Pistillate flower petals & $0=$ absent, $1=$ reduced, 2 = well-developed \\
Style division & $0=$ bifid, 1 = four-fid, 2 = multifid \\
Connation of styles & $0=$ absent, 1 = present \\
\hline
\end{tabular}

Table 2

Number of characters and comparative statistics for the maximum parsimony analyses of the molecular datasets.

\begin{tabular}{|c|c|c|c|c|}
\hline & ITS & $\operatorname{trnL}-F$ & psbA-trnH & $\begin{array}{l}\text { Chloroplast- } \\
\text { combined }\end{array}$ \\
\hline Total characters & 743 & 1155 & 767 & 1922 \\
\hline Constant characters & 428 & 901 & 434 & 1335 \\
\hline Variable characters & 315 & 254 & 333 & 587 \\
\hline Informative characters & 229 & 108 & 138 & 246 \\
\hline$\%$ Informative & 31 & 9 & 18 & 13 \\
\hline Trees retained & 220 & - & - & 209 \\
\hline Tree length & 838 & - & - & 826 \\
\hline $\mathrm{CI}$ & 0.5561 & - & - & 0.8257 \\
\hline RI & 0.6346 & - & - & 0.6346 \\
\hline
\end{tabular}

independent analyses of the nuclear and chloroplast data when appropriate.

\subsection{Analysis of ITS}

The parsimony search of the ITS data set retained 220 trees of length $(L)=838$, consistency index $(\mathrm{CI})=0.5561$, and retention in$\operatorname{dex}(\mathrm{RI})=0.6346$. The "sumt" command in MrBayes was used to compute the consensus of the post-burn-in trees and the posterior probability values from the Bayesian analysis of ITS (Fig. 1).

Results from all analytical approaches performed on this data set recovered a new circumscription of section Cleodora compared to that of Webster (1993). Three species placed by Webster (1993) in other sections are shown here to belong to section Cleodora, namely $C$. fragrans Kunth, previously placed in section Lasiogyne; and $C$. organensis and $C$. rottlerifolius, which were previously placed in section Cyclostigma. These three species emerge within a strongly supported clade (100\% PP, $75 \%$ BS) along with all of the sampled section Cleodora species (Fig. 1).

In the ITS phylogeny, section Cleodora emerges in a trichotomy with two other clades of Croton subgenus Geiseleria A.Gray (sensu Van Ee et al., in press), which together include sections Lamprocroton, Lasiogyne, Luntia, Eluteria, Barhamia, Medea, and Geiseleria (Fig. 1). The recently recognized section Cuneati (G.L. Webster) Riina \& Berry (Riina et al., 2010) is recovered sister to this trichotomy (Fig. 1). Nevertheless, within section Cleodora, two highly supported clades (100\% PP and 99\% BS each) are recovered (Fig. 1), which represent the two subsections of Cleodora that we describe here (subsections Sphaerogyni and Spruceani).

\subsection{Analysis of chloroplast trnL-F and trnH-psbA}

The parsimony search of the chloroplast data set retained 209 trees of $L=826, \mathrm{CI}=0.8257$, and $\mathrm{RI}=0.7725$. The consensus of the post-burn-in trees from the Bayesian analysis of the combined chloroplast MCMC chains is depicted in Fig. 2.

Similar to the ITS phylogeny, the results from all analytical approaches performed on the chloroplast data recovered a newly circumscribed section Cleodora compared to that of Webster (1993), with the same species ( $C$. fragrans, $C$. organensis, and $C$. rottlerifolius) emerging within a well supported (100\% PP, 61\% BS) section Cleodora clade (Fig. 2). However, the chloroplast phylogeny recovered, with strong Bayesian posterior probability support (94\% PP), section Cuneati sister to section Cleodora. The chloroplast results provide high support (100\% PP, 88\% BS) for subsection Spruceani, but only weak support (68\% PP, <50\% BS) for subsection Sphaerogyni (Fig. 2).

\subsection{Combined nuclear and chloroplast analysis}

The parsimony search of the combined data set retained four trees of $L=1686, \mathrm{CI}=0.6809$, and $\mathrm{RI}=0.6741$. The consensus of 


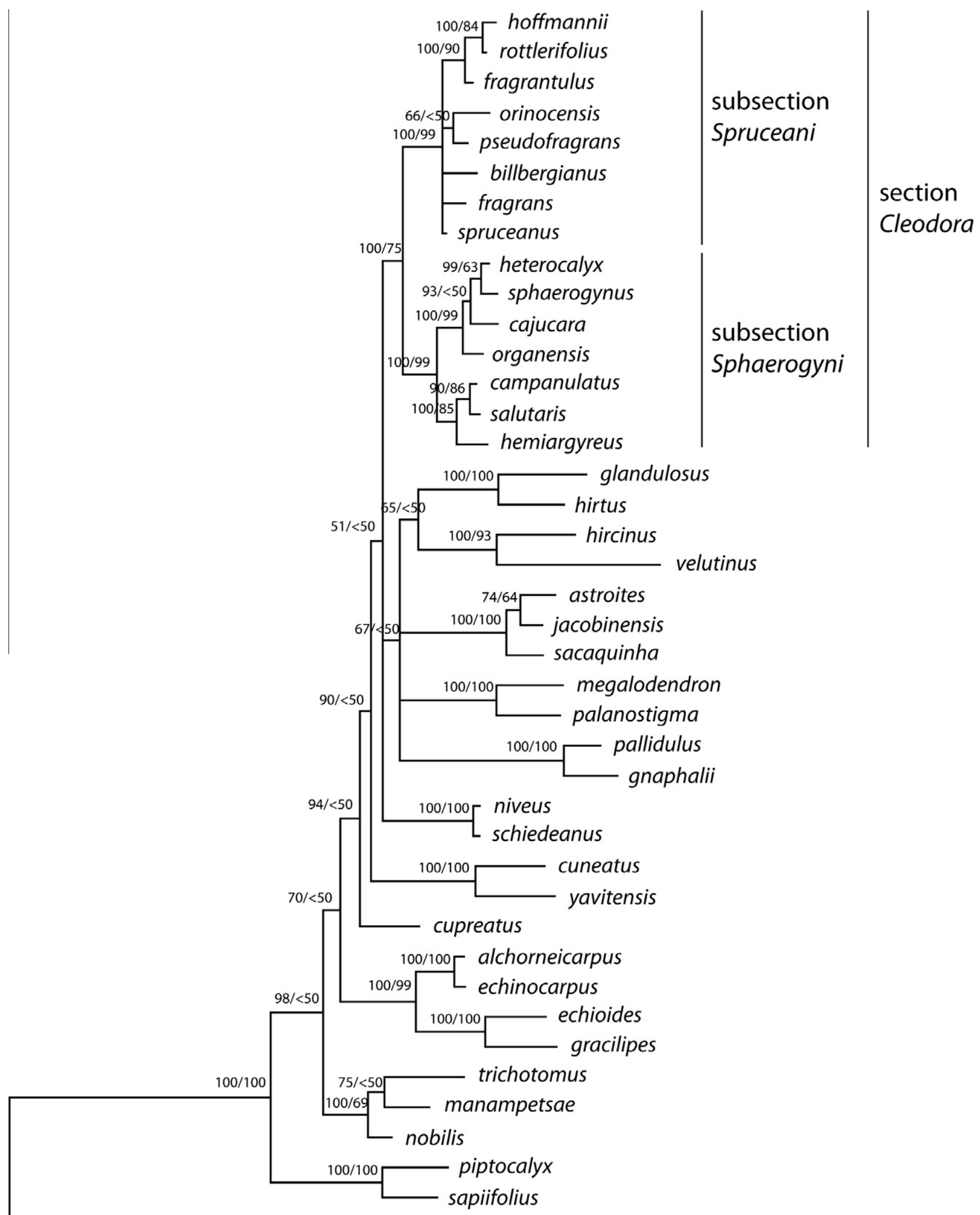

Astraea lobata

\section{Brasiliocroton mamoninha}

0.01 subs titutions/site

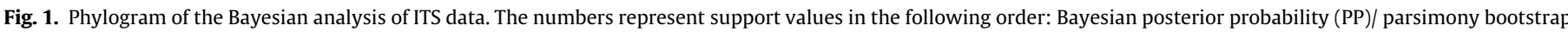
support (BP). 


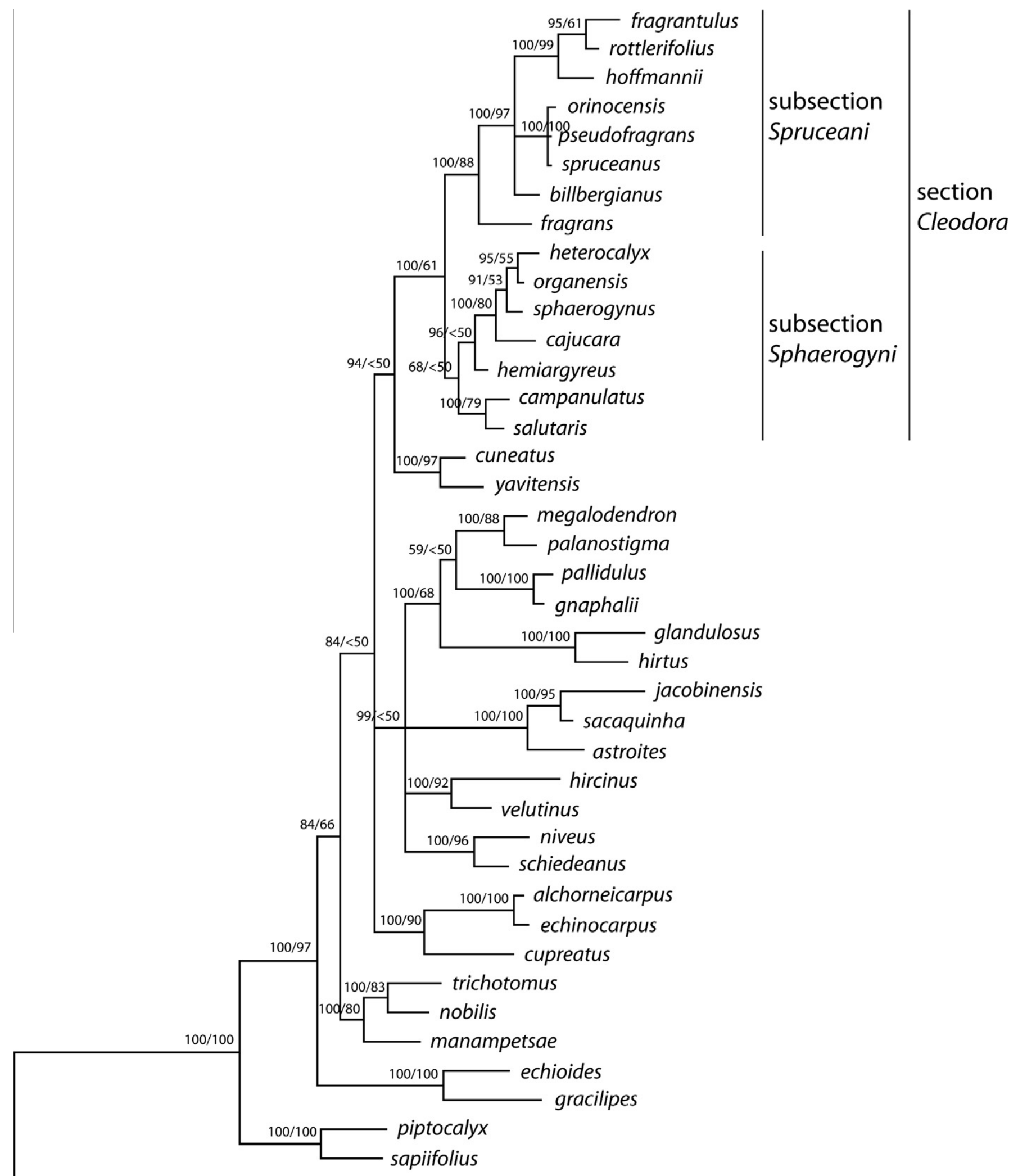

Astraea lobata

\section{Brasiliocroton mamoninha}

0.01 subs titutions/site

Fig. 2. Phylogram of the Bayesian analysis of combined chloroplast trnL-F and trnH-psbA data. The numbers represent support values in the following order: Bayesian posterior probability (PP)/parsimony bootstrap support (BP). 


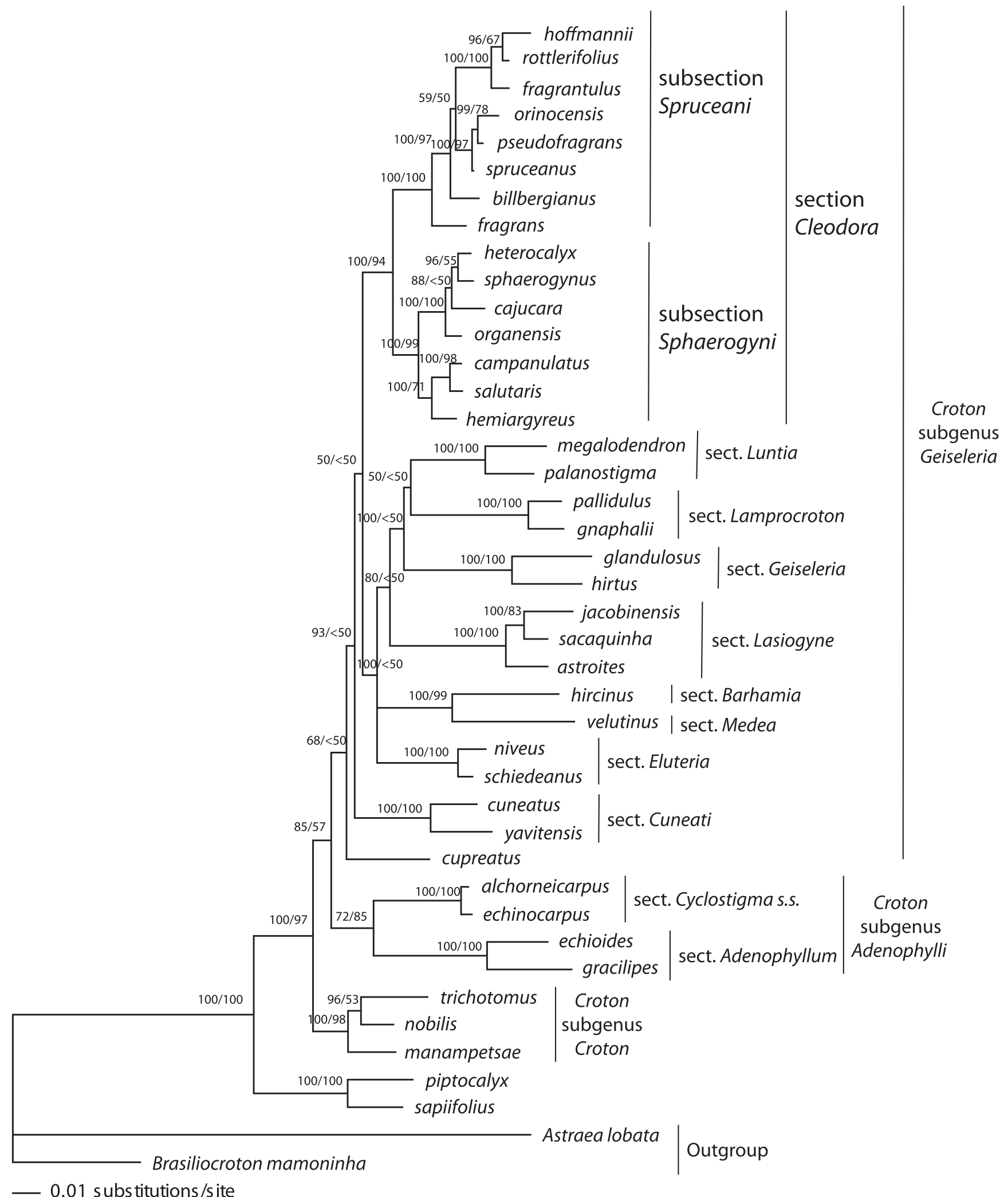

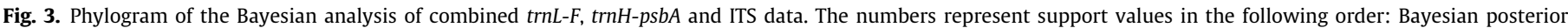
probability (PP)/parsimony bootstrap support (BP). Names on the right of vertical bars represent the sectional or informal clade assignment of the species.

the post-burn-in trees from the Bayesian analysis of the combined data MCMC chains is depicted in Fig. 3. All analyses performed on this data set recovered the same new circumscription of section Cleodora, with the same three previously non-section Cleodora species (Croton fragrans, C. organensis, and C. rottlerifolius) emerging within a highly supported clade (100\% PP, 94\% BS) along with the other members of section Cleodora sensu Webster (1993) (Fig. 3). 
In our combined phylogenetic results, section Cleodora is recovered within subgenus Geiseleria (Fig. 3). Subgenus Geiseleria emerges sister to subgenus Adenophylli (Griseb.) Riina, B.W. van Ee and Berry (sensu Van Ee et al., in press), and together these are sister to subgenus Croton (Fig. 3). The sister group of section Cleodora, although with weak support (50\% PP, $<50 \% \mathrm{BS}$ ), is a portion of the remainder of subgenus Geiseleria, which includes groups such as sections Lamprocroton, Geiseleria, and Cuneati (Fig. 3).

Section Cleodora is composed of two major sister clades, each of which are strongly supported (100\% PP each; 100\% and 99\% BS), and henceforth will be referred to as subsections. Subsection Sphaerogyni, depicted on the bottom in Fig. 3, includes the type of the section (Croton sphaerogynus), and subsection Spruceani is depicted on the top of Fig. 3.

\subsection{Morphological character state mapping}

Our results support previous claims that the morphological characters traditionally used in the systematic classification of Croton are highly homoplasious (Berry et al., 2005; Van Ee et al., 2008; Riina et al., 2009). Most of the clades, or sections, within Croton are defined by a suite of homoplasious characters, rather than by clear synapomorphies. The reconstruction of the evolution of trichome types within section Cleodora (Fig. 4A) reveals that the presence of lepidote trichomes is plesiomorphic, and is shared not only by section Cleodora but by other New World and Old World groups. Within section Cleodora, stellate trichomes appear to have evolved independently on two separate occasions (Fig. 4A).

The presence or absence of extrafloral nectaries on leaves is a frequently used diagnostic character within Croton. Although we have a relatively small sampling for tribe Crotoneae in our analysis, the inferred evolution of this character indicates that the presence of petiolar glands (Fig. 4B) is plesiomorphic for Croton, and for section Cleodora.

Croton flowers are usually arranged in thyrsoid inflorescences in which pistillate flowers are solitary at the lower nodes, and staminate flowers are found in cymules at the upper nodes. However, some species possess inflorescences with bisexual basal cymules, in which pistillate and staminate flowers occur together, as Webster (1993) described for sections Cleodora and Cyclostigma. The presence of bisexual cymules (Fig. 4C), as already pointed out by Van Ee et al. (2008), is homoplasious across the genus. The presence of inflorescences with bisexual basal cymules, used by Webster (1993) as one of the defining characters of section Cleodora, is thus a plesiomorphic character state for the section.

The optimization of the fusion of sepals in pistillate flowers onto the phylogeny (Fig. 4D) implies that the union of sepals only at the base is a plesiomorphic character state for Croton, found in almost the entire genus. The fusion of sepals in pistillate flowers up to half of their length has evolved at least three different times, once within section Cleodora subsection Spruceani (Croton fragrantulus Croizat, C. hoffmannii, and C. rottlerifolius), again in C. megalodendron and other members of section Luntia, and a third time in $C$. astroites Dryand. and other species of section Lasiogyne (Fig. 4D). The fusion of sepals almost to the apex has evolved only once in Croton, within section Cleodora (Fig. 4D), and it is an autapomorphy for $C$. spruceanus. Croton spruceanus is more closely related to species with sepals that are united only at the base, but together these are sister to the members of section Cleodora that have sepals fused up to half of their length (Figs. 3, 5A), suggesting that the full fusion of the sepals is probably not entirely independent of the partial fusion within section Cleodora.

Styles in Croton vary from simple (with three terminal stigmatic tips), to bifid (six terminal tips), four-fid (12 terminal tips), or multifid (more than 12 terminal tips). The inferred evolution of style division indicates that four-fid and multifid styles are highly homoplasious within Croton. Multifid styles are found throughout the genus, and therefore, the presence of multifid styles (Fig. 5A), one of the characters used by Webster (1993) to define section Cleodora, is plesiomorphic for the clade. A reduction from multifid to four-fid styles appears to have evolved at least twice within the section (Fig. 5A).

Pistillate flowers in Croton are generally apetalous, or with greatly reduced petals, and only rarely are conspicuous petals present in them. For practical reasons, in the cases in which small filamentous or glandular structures are present in the position of petals, we refer to these structures as reduced petals. Our results show that the presence of reduced petals is shared by a majority of New World Croton species (Fig. 5B), with a loss of this character in members of section Luntia (C. megalodendron and C. palanostigma Klotzsch), and in almost all members of section Cleodora except for the small clade consisting of $C$. hemiargyreus, $C$. salutaris Casar., and $C$. campanulatus Caruzo \& Cordeiro, which have petals reduced to ovoid glands.

The aestivation of pistillate flowers in Croton is generally valvate, or less often reduplicate-valvate (with the adjoining lobes valvate but then folding backwards and outwards at the same time). Reconstructing this character onto the molecular phylogeny indicates that valvate aestivation in pistillate flowers is the ancestral state for Croton (Fig. 5C). Overlapping aestivation (imbricate or quincuncial) is present in the pistillate flowers of all members of section Cleodora, except for the reduplicate-valvate aestivation in C. fragrans, and thus can be regarded as a synapomorphy for the clade.

\section{Discussion}

\subsection{Phylogenetic relationships}

The results of this study indicate that section Cleodora sensu Webster (1993) is largely monophyletic. These results corroborate those found by Riina et al. (2009), where Croton organensis and C. rottlerifolius (treated as $C$. warmingii in their study), both formerly placed in section Cyclostigma by Webster (1993), now emerge within a well supported clade with most members of Webster's section Cleodora. Besides these two species, Croton fragrans, a species placed by Webster (1993) in section Lasiogyne, also emerges within section Cleodora.

Section Cleodora is recovered as part of subgenus Geiseleria (Fig. 3), which is equivalent to clades C-5 through C-11 of Berry et al. (2005). Our results show that the chloroplast $(t r n L-F+t r n H-$ $p s b A$ ) and ITS trees are different, but not incompatible, regarding the sister group of section Cleodora. The chloroplast phylogeny strongly supports (94\% PP) section Cuneati as the sister group of section Cleodora (Fig. 2), whereas the ITS phylogeny places it in an unresolved position within subgenus Geiseleria (Fig. 1). The results from the chloroplast phylogeny are similar to those reported by Riina et al. (2010) in a study of arborescent clades of Neotropical Croton. Section Cuneati is morphologically similar to section Cleodora in its arborescent habit, presence of petiolar glands, bisexual cymules sometimes present, and low stamen number (10-20), but it differs from section Cleodora mainly by its discoid glands in the leaf margins (absent in section Cleodora), valvate sepals in the pistillate flowers (which are quincuncial, imbricate, or reduplicatevalvate in section Cleodora), free styles (which are united in section Cleodora), seeds ecarunculate or with a vestigial caruncle (compared to the small and usually reniform caruncle in section Cleodora), or sometimes with a distinctive aril (absent in section Cleodora).

Our results from the combined ITS and chloroplast data recover a section Cleodora clade with high support (100\% PP, 94\% BS) 
A

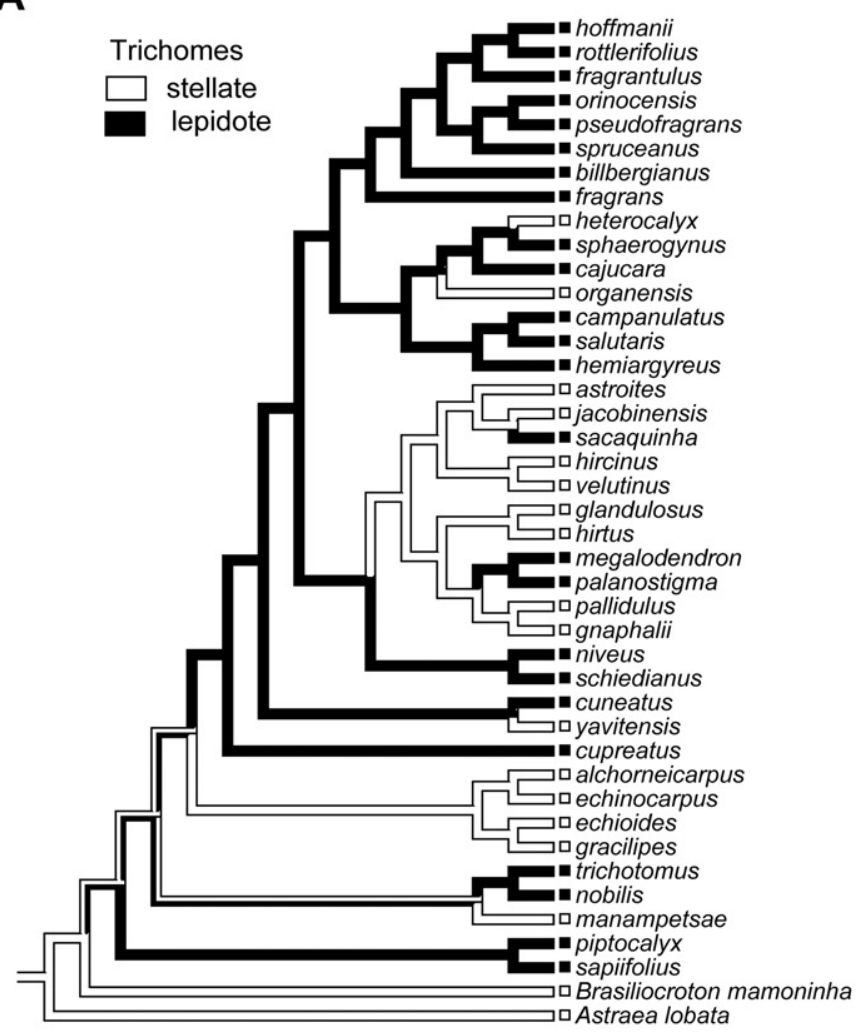

C

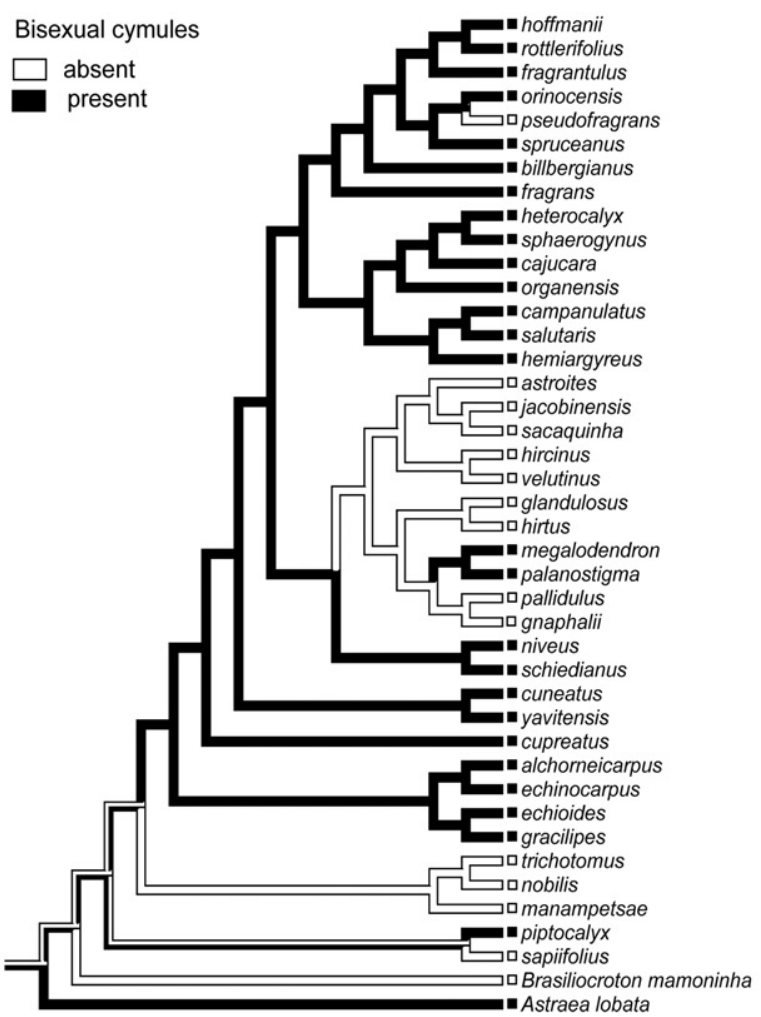

B
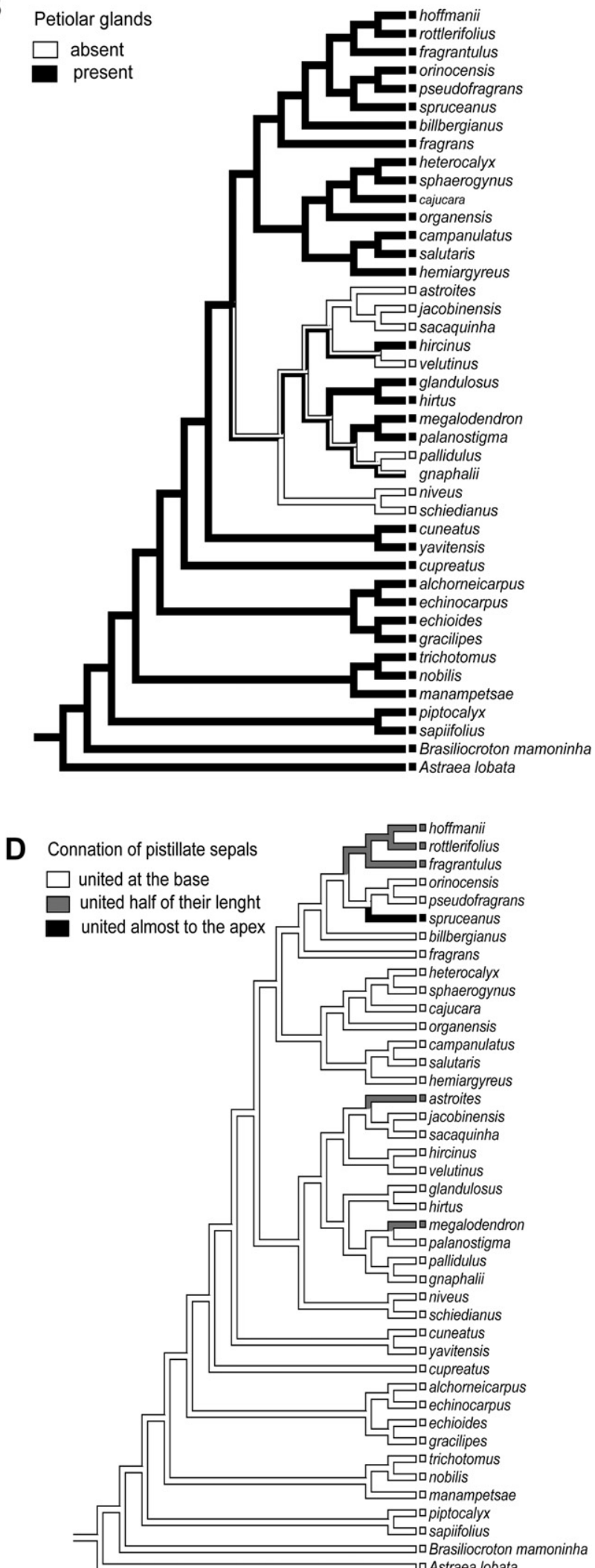

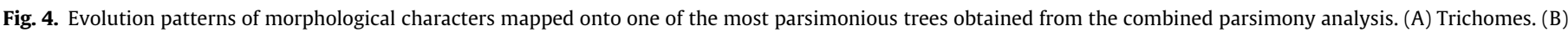
Petiolar glands. (C) Bisexual cymules. (D) Connation of pistillate sepals.

(Fig. 3). This clade has two main morphological synapomorphies: sepals of the pistillate flowers with some kind of overlap (Fig. 5C), and styles united at the base or higher, usually forming a tubular structure or a "crown" (Fig. 5D). All species of section
Cleodora are shrubs or small trees, with the exception of Croton organensis, which is a large tree up to $15 \mathrm{~m}$ tall. They grow along moist or dry forest borders, and they usually have reddish or clear latex. Other important features shared by the majority of the 
A

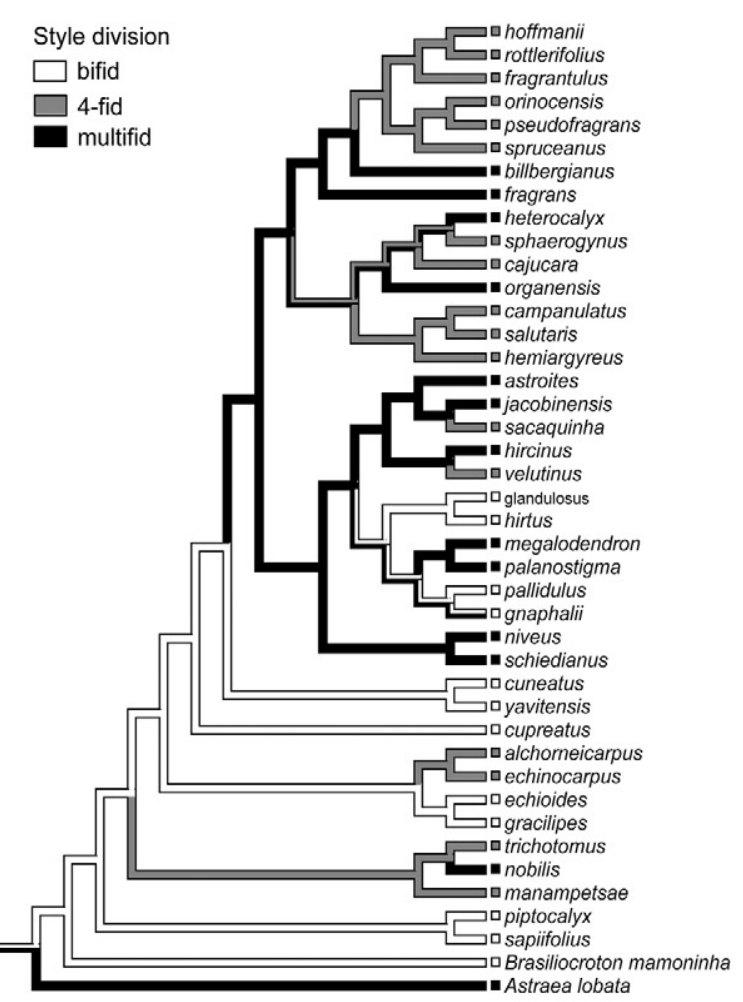

C

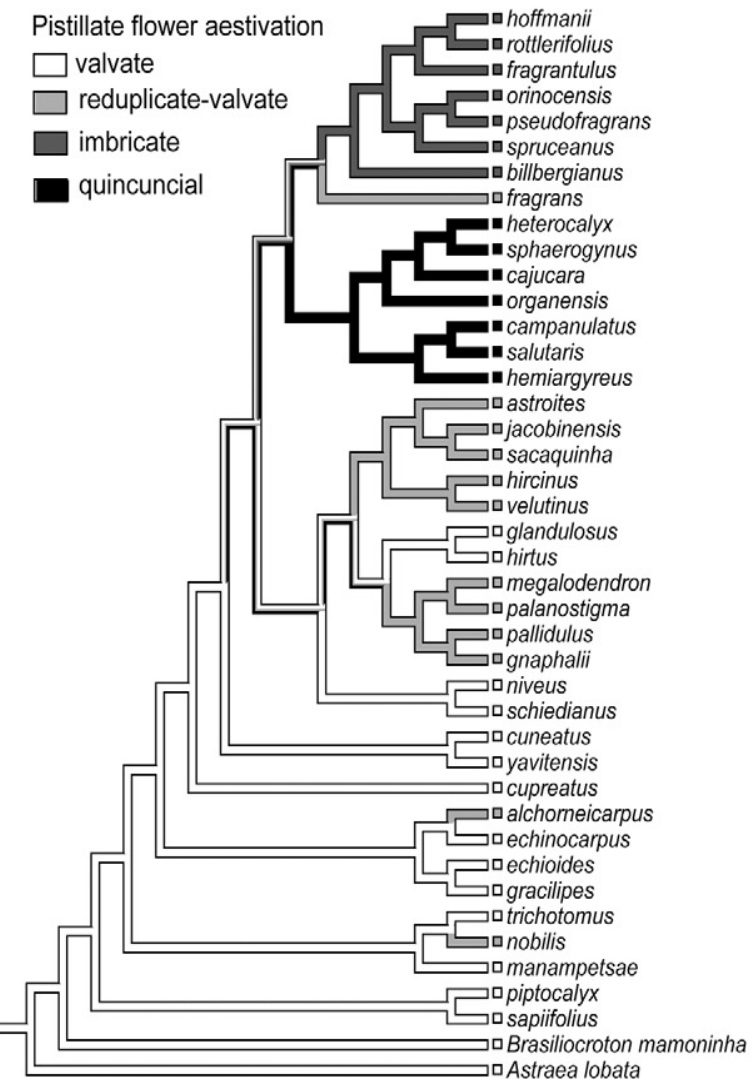

B

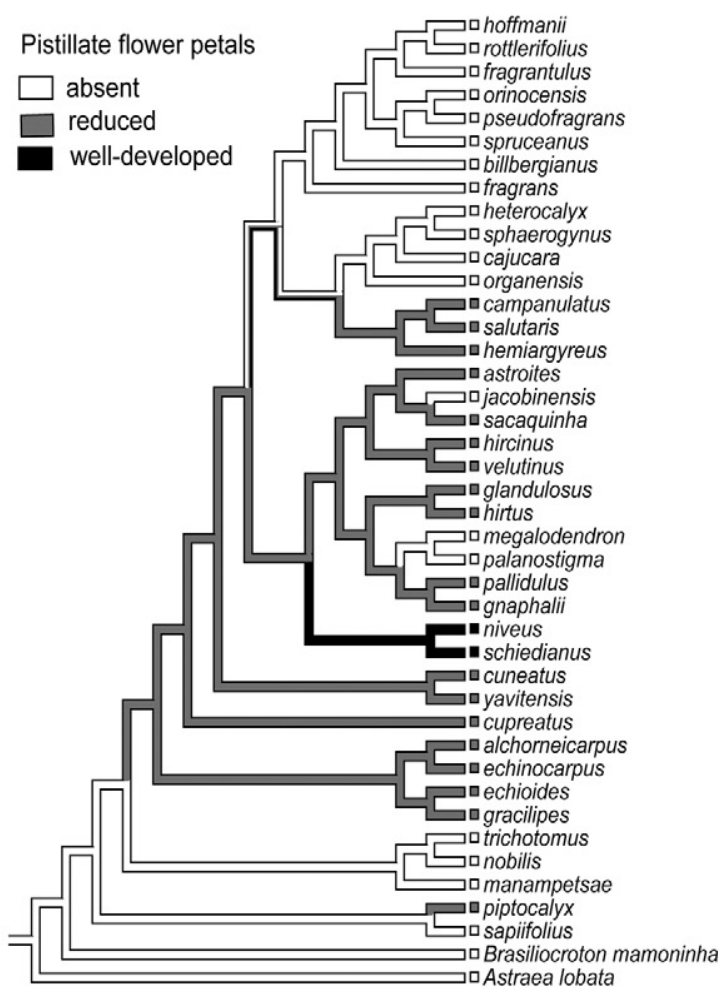

D

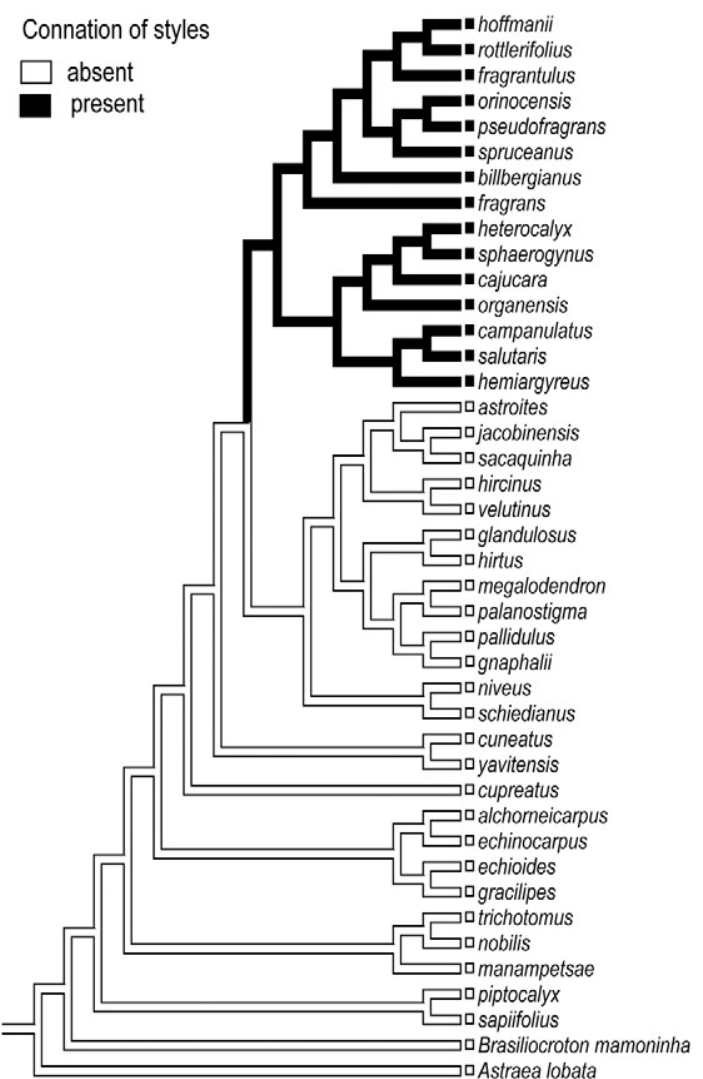

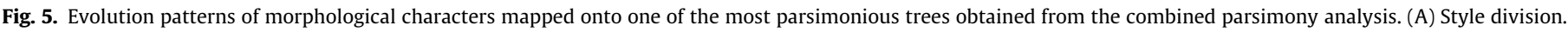
(B) Pistillate flower petals. (C) Pistillate flower aestivation. (D) Connation of styles.

species belonging to this clade (Figs. 6A-H) are the presence of lepidote trichomes of all subtypes (sensu Webster et al., 1996), leaves with a pair of glands at the apex of the petiole (acropetiolar glands) or near the base of the lamina (basilaminar glands), inflorescences with basal bisexual cymules (a plesiomorphic characteristic for the genus), sepals of the staminate flowers usually 
united half of their length, 15-25 stamens, sepals of the pistillate flowers united at the base or higher, and four-fid (12 terminal tips) or multifid ( $>12$ terminal tips) styles.

Within section Cleodora it is possible to identify two major, well-supported clades which we treat as subsections (Fig. 3). Subsection Sphaerogyni is predominantly Brazilian, with most species occurring in the Atlantic Rainforest of eastern Brazil, with the exception of Croton cajucara, an Amazonian species from lowland moist forests. Subsection Spruceani has species that occur in central and northwestern South America and southern Central America (with Croton billbergianus Müll.Arg. extending up to central Mexico), with the exception of $C$. rottlerifolius, which occurs in deciduous forests of Brazil, and C. fragrantulus, which occurs in similar vegetation in eastern Bolivia and central Peru.

Subsection Sphaerogyni, which includes the type species of section Cleodora (Croton sphaerogynus), is supported by a morphological synapomorphy, namely, the sepals of the pistillate flowers with quincuncial aestivation. Other features shared among species within subsection Sphaerogyni are globose fruits, sepals of pistillate flowers that are usually fleshy at the base, and pistillate flowers with a disk that is usually segmented.

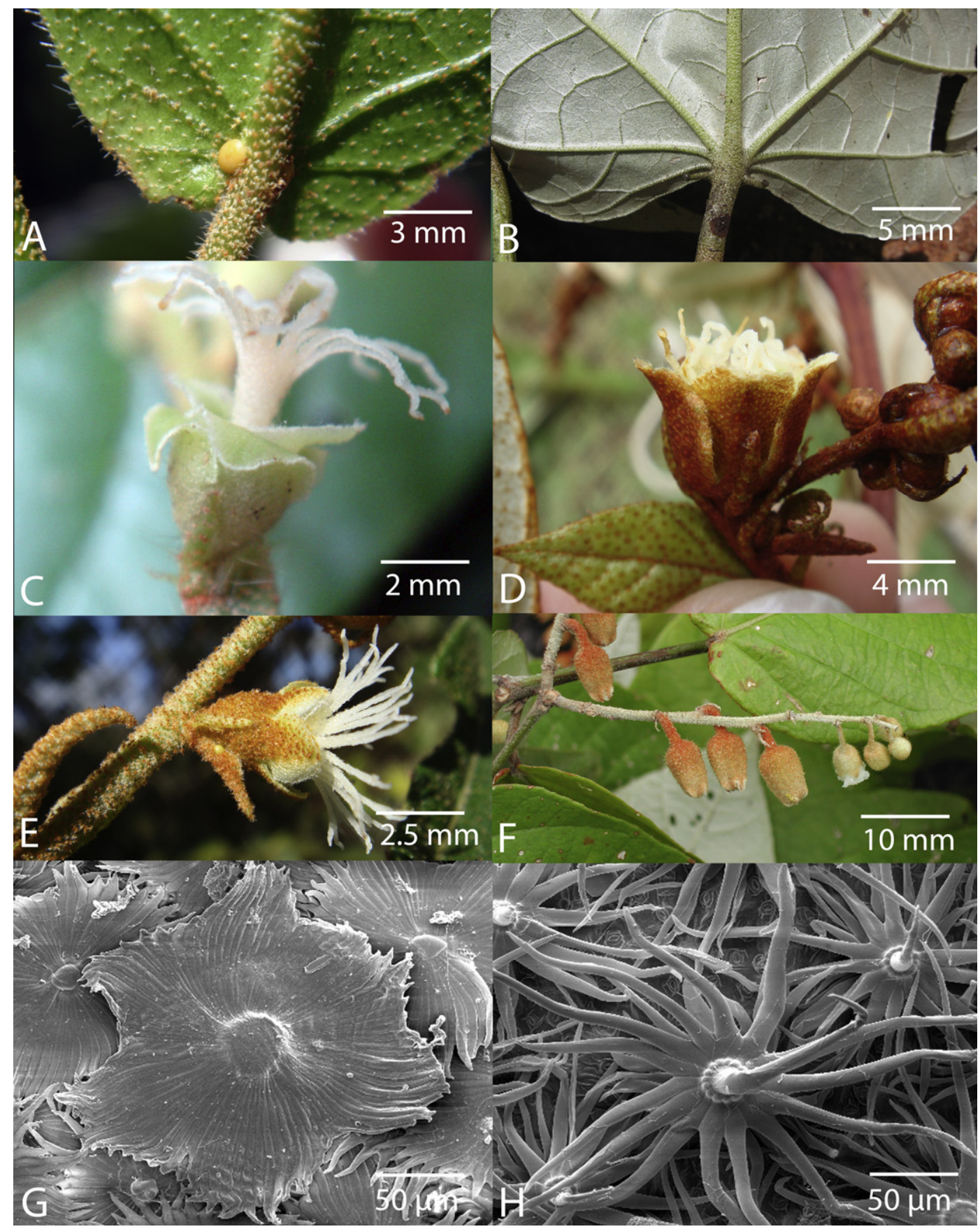

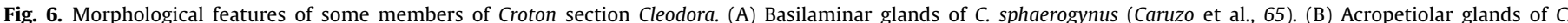

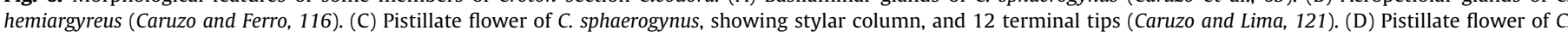

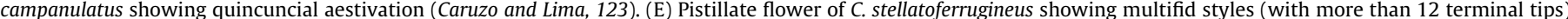

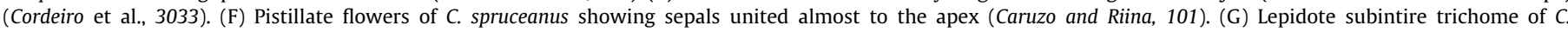
campanulatus (Caruzo et al., 93). (H) Adpressed-stellate trichomes of C. spruceanus with a porrect central radius (Caruzo and Riina, 101). (all images by the first author). 
Within subsection Sphaerogyni, two highly supported groups (each with $100 \%$ BS and PP) can be recognized (Fig. 3): the first (bottom) is an entirely lepidote clade with the typical subentire scales (Croton salutaris, C. campanulatus, and C. hemiargyreus), and the other one (top) consists of species that have appressed-stellate or multiradiate trichomes and lack lepidote subentire trichomes ( $C$. heterocalyx, C. sphaerogynus, C. cajucara, and C. organensis).

Our results show that the nuclear ITS and chloroplast trees are discordant about the exact placement of Croton hemiargyreus within subsection Sphaerogyni (Figs. 1 and 2). ITS data (Fig. 1) support $C$. hemiargyreus as sister to $C$. salutaris $+C$. campanulatus, whereas the chloroplast data (Fig. 2) place it sister to the other members of the subsection. However, morphology is consistent with the placement of this species as sister to $C$. salutaris $+C$. campanulatus, as recovered in the ITS (Fig. 1) and combined (Fig. 3) phylogenies. The group consisting of $C$. hemiargyreus, $C$. salutaris, and $C$. campanulatus is strictly arborescent, and is the only one within section Cleodora that is characterized by subentire lepidote trichomes, long stipitate acropetiolar glands, and apparently monochlamydeous pistillate flowers with petals reduced to ovoid glands.

The second group in subsection Sphaerogyni as recovered in the combined phylogeny (Croton organensis, C. cajucara, C. heterocalyx, and $C$. sphaerogynus; Fig. 3) shares appressed-stellate, multiradiate, and stellate trichomes, as well as the presence of sessile basilaminar glands. Moreover, with the exception of $C$. organensis, these species are usually found in places with sandy soils. Croton organensis is supported as the sister species to the rest of this clade, followed by $C$. cajucara, which is recovered sister to $C$. heterocalyx and $C$. sphaerogynus. Within this group, both $C$. cajucara and C. heterocalyx have been reported to contain linalool, an alcohol with antimicrobial properties widely used in the perfume industry, making this clade interesting for bioprospecting studies. Since our results indicate that $C$. sphaerogynus is one of the closest relatives of $C$. cajucara, we suggest that it is an excellent candidate for future bioprospecting studies.

Subsection Spruceani is composed of species from moist to seasonally dry forests of northern and western South America, Central America, and Mexico, as well as two from seasonally dry forests of eastern Brazil, Peru, and Bolivia. This subsection can be generally characterized by the presence of appressed-stellate trichomes sometimes associated with other types of trichomes, imbricate aestivation in the pistillate flowers, sepals of the pistillate flowers that are usually united at least half of their length, and subglobose to ellipsoid fruits. Croton fragrans, followed by C. billbergianus, are supported as sister to the rest of the species (Fig. 3). These remaining species share four-fid styles, and are clustered into two highly supported subclades (each with 100\% BS and PP): the first (top) contains species of seasonally dry forests of South America and Central America ( $C$. fragrantulus, $C$. rottlerifolius, and $C$. hoffmannii) whose distributions fall within the area of the dry "Pleistocenic arc" reported by Pennington et al. (2006) and Prado (2000). The species of this group share the presence of stellate and appressed-stellate trichomes, acropetiolar leaf glands, and campanulate pistillate flowers. The second clade (bottom) is composed of species from lowland Amazon rainforests (C. spruceanus, C. orinocensis, and C. pseudofragrans).

Relationships among species of the first group (Croton fragrantulus, $C$. rottlerifolius, and $C$. hoffmannii) are not congruent between the ITS and chloroplast phylogenies. ITS (Fig. 1) supports C. rottlerifolius as sister to $C$. hoffmannii, while the chloroplast data (Fig. 2) place $C$. fragrantulus sister to $C$. rottlerifolius. Morphology is consistent with the placement of $C$. rottlerifolius as the sister species of $C$. hoffmannii as recovered in the ITS and combined phylogenies. These two species ( $C$. rottlerifolius and $C$. hoffmannii) are morphologically more similar to each other than either one is to $C$. fragrantulus. Some of the morphological characteristics shared between $C$. rottlerifolius and $C$. hoffmannii are the presence of cylindrical branches (vs. flat branches in C. fragrantulus), the presence of blackened trichomes on the pistillate flowers, and sepals of the pistillate flowers with a distinct texture at the margin.

\subsection{Character evolution}

Trichome types have been widely used in the systematic classification of Croton (Webster et al., 1996). Trichomes within the genus vary between two basic types, stellate and lepidote, although there are intermediate forms. Trichome type has transitioned between stellate and lepidote multiple times during the evolution of Croton (Fig. 4A).

The total fusion of the sepals in Croton spruceanus (Fig. 6F) might have some implications for its pollination biology, but field studies need to be done to determine its pollination system. Most Croton species are visited by different kinds of insects, and their flowers are either insect or wind pollinated (Domínguez and Bullock, 1989; Bullock, 1994; Decker and Pilson, 2000; Freitas et al., 2001), so it will be interesting to study the reproductive biology of $C$. spruceanus to determine whether its unique calyx morphology is associated with a more specific pollinator, such as hummingbirds.

Styles in Croton are usually free, but connation of the styles at the base or higher is present in all members of section Cleodora. Despite being a synapomorphy for the entire section Cleodora clade, the connation of styles can be found in other Croton species not sampled in our study, such as in some Malagasy species (e.g. $C$. argyrodaphne Baill.), and some Neotropical species belonging to section Argyroglossum (e.g. C. blanchetianus Baill.).

Two different types of overlapping aestivation in pistillate flowers are present within section Cleodora, quincuncial aestivation in subsection Sphaerogyni, and imbricate aestivation in subsection Spruceani, with one species in subsection Spruceani, Croton fragrans, displaying reduplicate-valvate aestivation. The clade sister to section Cleodora has valvate and reduplicate-valvate aestivation. Therefore, our results support an evolutionary trend within Croton from pistillate flowers with valvate or reduplicate-valvate aestivation to pistillate flowers with imbricate or quincuncial aestivation in species of section Cleodora (Fig. 5C).

\subsection{A new circumscription for the section}

Croton section Cleodora (Klotzsch) Baill., Étude Euphorb.: 369. 1858. $\equiv$ Cleodora Klotzsch, Arch. Naturgesch 7: 196. 1841. Type: Cleodora sellowiana Klotzsch (=Croton sphaerogynus Baill.).

=Croton section Stolidanthus Baill., Adansonia 4: 323. 1864. Type: Croton heterocalyx Baill. (lectotype, designated by Webster, 1993: 800).

Trees or shrubs, monoecious, generally laticiferous, latex clear to reddish; covered with appressed-stellate, stellate-lepidote, or lepidote subentire trichomes, rarely stellate or multiradiate trichomes. Leaves alternate, with a pair of acropetiolar or basilaminar, usually sessile, rarely stipitate, glands. Inflorescences terminal, rarely axillary, basal cymules bisexual, rarely unisexual or falsely unisexual; staminate flowers dichlamydeous, campanulate, rarely subcampanulate, valvate or slightly imbricate aestivation, sepals usually united up to half of their length, stamens 15-25; pistillate flowers monochlamydeous, rarely with petals reduced to glands, slightly zygomorphic or actinomorphic, sessile or pedicellate, campanulate, flask-shaped or urceolate, imbricate or quincuncial aestivation, styles four-fid or multifid, united at the base or further up, usually forming a "crown" or a column. Fruits globose, ellipsoid or subglobose (usually trigonal), with calyx persistent and sometimes strongly accrescent; seeds with a small caruncle, without aril.

Species included: Croton billbergianus Müll.Arg., C. cajucara Benth., C. campanulatus Caruzo \& Cordeiro, C. sexmetralis Croizat, 
C. fragrans Kunth, C. fragrantulus Croizat, C. hemiargyreus Müll.Arg., C. heterocalyx Baill., C. hoffmannii Müll.Arg., C. organensis Baill., C. orinocensis Müll.Arg., C. pseudofragrans Croizat, C. rottlerifolius Baill., C. rufolepidotus Caruzo \& Riina, C. salutaris Casar., C. sphaerogynus Baill., C. spruceanus Benth., C. stellatoferrugineus Caruzo and Cordeiro.

There are two species excluded from section Cleodora in its new circumscription, namely Croton maracayuensis Chodat \& Hassl. (=C. floribundus Spreng.), which was placed in section Cleodora by Webster (1993), and Croton velutinus Baill., which was placed by Baillon (1864) in his section Stolidanthus. Croton maracayuensis was first treated as a synonym of $C$. floribundus by Bernardi (1984). Webster (1993) placed Croton floribundus in section Argyroglossum mainly due to its leaves without glands, inflorescences without bisexual cymules, 10-15 stamens, and reduplicate-valvate sepals in the pistillate flowers, which are all characteristics that exclude this species from section Cleodora. Although Webster (1993) had synonymized section Stolidanthus under section Cleodora, he did not include Croton velutinus in the latter section, or in any other section recognized in his synopsis. The subshrubby habit, stellate indumentum, leaves without petiolar or basilaminar glands, inflorescences without bisexual cymules, between 10-12 stamens, and reduplicate-valvate sepals of the pistillate flowers of this species exclude it from section Cleodora. The best placement for $C$. velutinus, considering all the features above is in section Barhamia (Klotzsch) Baill.

Species of Croton section Cleodora fall into two distinct groups, recognized here as subsections:

Croton subsection Sphaerogyni Caruzo, subsect. nov. - Aestivatio sepalis floribus femineis quincuncialis, sepalis saepe carnosis, fructibus globosis vel ellipsoideus. - Type: Croton sphaerogynus Baill.

Sepals of pistillate flowers with quincuncial aestivation, free or united only at the base; sepals usually fleshy at the base; disk usually segmented. Fruits globose or ellipsoid.

Species included here occur in eastern Brazil, with the exception of Croton cajucara, an Amazonian species occurring in Bolivia, Brazil, Peru, and Venezuela. Members of subsection Sphaerogyni typically occupy moist forests, except for $C$. heterocalyx, which occurs in seasonally dry forests and in "restinga" forests in eastern Brazil.

Species included: Croton cajucara Benth., C. campanulatus Caruzo \& Cordeiro, C. hemiargyreus Müll.Arg., C. heterocalyx Baill., C. organensis Baill., C. rufolepidotus Caruzo \& Riina, C. salutaris Casar., C. sphaerogynus Baill., C. stellatoferrugineus Caruzo and Cordeiro.

Croton rufolepidotus Caruzo and Riina, a recently described species from Antioquia, Colombia is a member of this subsection based on its similarity with C. salutaris (Caruzo et al., 2010b). Similarly, another recently described species, $C$. stellatoferrugineus Caruzo \& Cordeiro (Caruzo et al., 2010a), fits the morphological definition of this subsection and therefore is included as well.

Croton subsection Spruceani Caruzo, subsect. nov. - Aestivatio sepalis floribus femineis imbricatis, sepalis non carnosis, fructibus subglobosis. - Type: Croton spruceanus Benth.

Sepals of pistillate flowers with imbricate aestivation, usually united at least half of their length; sepals not fleshy; disk entire. Fruits subglobose, usually trigonal.

Species of subsection Spruceani occur somewhat disjunctly in moist habitats of central and northwestern South America, Central America up to central Mexico, and then in semideciduous forests of eastern Bolivia, central Peru and Brazil (Croton fragrantulus and $C$. rottlerifolius).

Species included: Croton billbergianus Müll.Arg., C. sexmetralis Croizat, C. fragrans Kunth, C. fragrantulus Croizat, C. hoffmannii Müll.Arg., C. orinocensis Müll.Arg., C. pseudofragrans Croizat, C. rottlerifolius Baill., C. spruceanus Benth.

\section{Acknowledgments}

This paper is part of the senior author's Ph.D. dissertation in the Department of Botany of the Biosciences Institute of the University of São Paulo (USP). Thanks are due to the National Council of Research of Brazil (CNPq), the International Association for Plant Taxonomy (IAPT), a Cuatrecasas Award from the Smithsonian Institution for the financial support provided to M.B.R.C., and the National Science Foundation for Grants DEB-0212481 and DEB0508725. Hope Draheim (University of Michigan) helped M.B.R.C. and R.R. with laboratory procedures. M.B.R.C. and R.R. thank the staff of the HUEFS, IAN, SP, MYF, TFAV, and VEN for their help during field work.

\section{Appendix A}

Taxa, localities, vouchers, and GenBank accession numbers for all sequences analyzed. Taxon, Origin, Voucher, GenBank accession numbers: (ITS; trnH-psbA; trnL-F). Missing data: -.

Astraea lobata (L.) Klotzsch, BRAZIL, Bahia, Van Ee 486 (WIS), (EU586945; -; -); A. lobata, BRAZIL, Bahia, Van Ee 487 (WIS), (-; -; HM044768); A. lobata, PUERTO RICO, Van Ee 549 (WIS), (-; HM044809; -); Brasiliocroton mamoninha P.E.Berry \& Cordeiro, BRAZIL, Espirito Santo, Pirani 4947 (SPF), (EU586944; HM044810; EU586998); Croton alchorneicarpus Croizat, BRAZIl, São Paulo, Caruzo 71 (SP), (HM044788; -; HM044769); C. alchorneicarpus, BRAZIL, Rio de Janeiro, Riina 1529 (WIS), (-; HM044811; -); C. astroites Dryand., PUERTO RICO, Van Ee 537 (WIS), (EU586902; HM044812; EU586955); C. billbergianus Müll.Arg., COSTA RICA, Alajuela, Van Ee 342 (WIS), (EU477998; HM044813; EU478148); C. cajucara, BRAZIL, Caruzo 96 (SP), (HM044789; HM044814; HM044770); C. campanulatus Caruzo \& Cordeiro, BRAZIL, Rio de Janeiro, Caruzo 93 (SP), (HM044790; HM044815; HM044771); C. cuneatus Klotzsch, PERU, Riina 1491 (WIS), (EU497735; HM044816; AY794698); C. cupreatus Croizat, ECUADOR, Pichincha, Riina 1408 (WIS), (EU586919; HM044817; EU586974); C. echioides Baill., BRAZIL, Piauí, Carneiro-Torres 795 (HUEFS), (EU586907; HM044818; EU586967); C. echinocarpus Müll.Arg., BRAZIL, Minas Gerais, Riina 1371 (WIS), (EU586922; -; EU586979); C. echinocarpus, BRAZIL, Rio de Janeiro, Riina 1519 (WIS), (-; HM044819; -); C. fragrans, VENEZUELA, Cojedes, Riina 1824 (MICH), (HM044791; HM044820; HM044772); C. fragrantulus Croizat, BOLIVIA, Santa Cruz, Foster 424 (MO), (HM044791; HM044821; HM044773); C. glandulosus L., U.S.A., Wisconsin, Van Ee 512 (WIS), (EU478066; HM044822; EU497713); C. gnaphalii Baill., ARGENTINA, Entre Rios, Belgrano 423 (SI), (EU586940; HM044846; EU586994); C. gracilipes Baill., BOLIVIA, Santa Cruz, Nee 47412 (NY), (EU586909; HM044823; EU586962); C. hemiargyreus Müll.Arg., BRAZIL, Minas Gerais, Caruzo 114 (SP), (HM044793; HM044824; HM044774); C. heterocalyx Baill., BRAZIL, Bahia, Caruzo 108 (SP), (HM044794; HM044825; HM044775); C. hircinus Vent., VENEZUELA, Caracas, Riina 1291 (WIS), (EU477889; -; EU478127); C. hirtus L'Her., BRAZIL, Lima 345 (SPF), (EU478070; -; EU478160); C. hoffmannii Müll.Arg., COSTA RICA, Cartago, Van Ee 598 (WIS), (EF421773; HM044826; EF408111); C. jacobinensis Baill., BRAZIL, Bahia, Carneiro-Torres 789 (HUEFS), (HM044795; HM044827; HM044776); C. malambo Karst., COLOMBIA, Bolivar, Zarucchi 3856 (MO), (-; HM044828; -); C. manampetsae Leandri, MADAGASCAR, Toliar, Van Ee 950 (MICH), (HM044796; HM044829; HM044777); C. niveus Jacq., COSTA RICA, Guanacaste, Van Ee 284 (WIS), (EU478046; -; EU478155); C. niveus, MEXICO, Oaxaca, León 52 (DAV), (-; HM044830; -); C. nobilis Baill., MADAGASCAR, Toliar, Van Ee 938 (MICH), (HM044797; HM044831; HM044778); C. organensis Baill., BRAZIL, Rio de Janeiro, Caruzo 90 (WIS), (EU586914; HM044832; EU586969); C. orinocensis Müll.Arg., VENEZUELA, Amazonas, Riina 
1818 (MICH), (HM044799; HM044834; HM044779); C. palanostigma Klotzsch, PERU, Loreto, Riina 1492 (WIS), (EU586943; HM044835; EU586997); C. pallidulus Baill., BRAZIl, São Paulo, Caruzo 31 (SP), (EU586939; - EU586993); C. piptocalyx Müll.Arg., BRAZIL, São Paulo, Caruzo 54 (SP), (EF421791; HM044836; -); C. piptocalyx, BRAZIL, São Paulo, Riina 1533 (-; -; EF408148); C. pseudofragrans Croizat, PERU, Loreto, Woodward s.n. (MICH), (HM044800; HM044837; HM044780); C. rottlerifolius Baill., BRAZIL, São Paulo, Caruzo 56 (SP), (-; HM044838; -); C. rottlerifolius, BRAZIL, São Paulo, Riina 1534 (WIS), (HM044801; -; HM044781); C. sacaquinha Croizat, BRAZIL, Pará, Caruzo 97 (SP), (HM044802; HM044839; HM044782); C. salutaris Casar., BRAZIl, Rio de Janeiro, Caruzo 89 (SP), (HM044804; HM044840; HM044783); C. sapiifolius Müll.Arg., BRAZIL, Bahia, Lima 667 (CEPEC), (EF421754; HM044841; EF408150); C. schiedeanus Schltdl., MEXICO, Yucatan, Van Ee 458 (WIS), (EU478051; HM044842; EU478156); C. sphaerogynus Baill., BRAZIL, Rio de Janeiro, Van Ee 505 (WIS), (HM044805; HM044843; HM044784); C. spruceanus Benth., BRAZIL, Pará, Caruzo 101 (SP), (-; HM044844; HM044785); C. spruceanus, COLOMBIA, Valle del Cauca, Baker 6493 (MO), (HM044806; -;-); C. velutinus Baill., BRAZIL, Bahia, Carneiro-Torres 902 (HUEFS), (HM044807; -; HM044786); C. trichotomus Geiseler, MADAGASCAR, Toamasina, Van Ee 991 (MICH), (HM044808; HM044845; HM044787); C. yavitensis Croizat, BOLIVIA, Beni, Beck 5710 (LPB), (EU586918; HM044847; EU586973).

\section{References}

Alviano, W.S., Mendonça, R.R., Alviano, D.S., Bizzo, H.R., Souto-Padron, T., Rodrigues, M.L., Bolognese, A.M., Alviano, C.S., Souza, M.M.G., 2005. Antimicrobial activity of Croton cajucara Benth.: linalool-rich essential oil on artificial biofilms and planktonic microorganisms. Oral Microbiol. Immunol. 20, 101-105.

Araújo, V.C., Corrêa, G.C., Maia, J.G.S., Silva, M.L., Gottlieb, O.R., Marx, M.C. Magalhães, M.T., 1971. Óleos essenciais da Amazônia contendo linalol. Acta Amaz. 1, 45-47.

Baillon, H., 1858. Etude Générale du Groupe des Euphorbiacées. Victor Masson, Paris.

Baillon, H., 1864. Euphorbiaceés Americaines. Adansonia 4, 257-377.

Bernardi, L., 1984. Contribución a la dendrología paraguaya. I. Boissiera 35, 1-341.

Berry, P.E., Hipp, A.L., Wurdack, K.J., Van Ee, B.W., Riina, R., 2005. Molecular phylogenetics of the giant genus Croton and tribe Crotoneae (Euphorbiaceae sensu stricto) using ITS and trnL-trnF DNA sequence data. Am. J. Bot. 92, 15201534.

Brito, N.M.B., Silva-Neto, G.P.N., Torres, I.O., Pacheco, F.T., Batista, L.L., 2006. Efeito do extrato de sacaca (Croton cajucara Benth.) nas glândulas mamárias de ratas submetidas à ooforectomia. Rev. Para Med. 20, 15-18.

Bullock, S.H., 1994. Wind pollination of neotropical dioecious trees. Biotropica 26, $172-179$.

Burger, W., Huft, M., 1995. Flora costaricensis: Euphorbiaceae. Fieldiana 36, 1-169.

Campos, A.R., Albuquerque, F.A.A., Rao, V.S.N., Maciel, M.A.M., Pinto, A.C., 2002. Investigations on the antinociceptive activity of crude extracts from Croton cajucara leaves in mice. Fitoterapia 73, 116-120.

Caruzo, M.B.R., Cordeiro, I., 2007. Sinopse da tribo Crotoneae Dumort. (Euphorbiaceae s.s.) no Estado de São Paulo, Brasil. Hoehnea 34, 571-585.

Caruzo, M.B.R., Cordeiro, I., Berry, P.E., Riina, R., 2010a. A new species of Croton section Cleodora (Euphorbiaceae s.s.) from Minas Gerais, Brazil. Phytotaxa 3 , 27-33.

Caruzo, M.B.R., Riina, R., Cordeiro, I., Berry, P.E., 2010b. Croton rufolepidotus (Euphorbiaceae s.s.), a new species from Colombia. Novon 20, 248-251.

Carvalho, J.C.T., Silva, M.F.C., Maciel, M.A.M., Pinto, A.C., Nunes, D.S., Lima, R.M Bastos, J.K., Sarti, S.J., 1996. Investigation of anti-inflammatory and antinociceptive activities prototype of trans-dehydrocrotonin, a 19-norclerodane diterpene from Croton cajucara. Part 1. Planta Med. 62, 402-404.

Cordeiro, I., Berry, P.E., Caruzo, M.B., Van Ee, B.W., 2008. Croton laceratoglandulosus (Euphorbiaceae s.s.), a new glandular-stipulate species from Brazil and Bolivia and its systematic position based on molecular analysis. Bot. J. Linn. Soc. 158, 493-498.

Costa, A.M.L., Silva, J.C.R., Campos, A.R., Rao, V.S.N., Maciel, M.A.M., Pinto, A.C., 1999. Antioestrogenic effect of trans-dehydrocrotonin, a nor-clerodane diterpene from Croton cajucara Benth. in rats. Phytother. Res. 13, 689-691.

Decker, K.L., Pilson, D., 2000. Biased sex ratios in the dioecious annual Croton texensis (Euphorbiaceae) are not due to environmental sex determination. Am. J. Bot. 87, 221-229.

Domínguez, C.A., Bullock, S.H., 1989. La reproducción de Croton suberosus en luz y sombra. Rev. Biol. Trop. 37, 1-10.

Farias, R.A.F., Neto, M.F.O., Viana, G.S.B., Rao, V.S.N., 1996. Effects of Croton cajucara extract on serum lipids of rats fed a high fat diet. Phytother. Res. 10, 697-699.
Farias, R.A., Rao, V.S., Viana, G.S., Silveira, E.R., Maciel, M.A., Pinto, A.C., 1997. Hypoglycemic effect of trans-dehydrocrotonin, a nor-clerodane diterpene from Croton cajucara. Planta Med. 63, 558-560.

Farris, J.S., Kallersjo, M., Kluge, A.G., Bult, C., 1994. Testing significance on incongruence. Cladistics 10, 315-319.

Freitas, L., Bernardello, G., Galetto, L., Paoli, A.A.S., 2001. Nectaries and reproductive biology of Croton sarcopetalus (Euphorbiaceae). Bot. J. Linn. Soc. 136, 267-277. Frodin, D.G., 2004. History and concepts of big plant genera. Taxon 53, 753-776.

Govaerts, R., Frodin, D.G., Radcliffe-Smith, A., 2000. World Checklist and Bibliography of Euphorbiaceae (and Pandaceae), vol. 4. Royal Botanic Gardens, Kew, England.

Grassi-Kassisse, D.M., Wolf-Nunes, V., Miotto, A.M., Farias-Silva, E, Souza-Brito, A.R.M., Nunes, D.S., Spadari-Bratfisch, R.C., 2003. Sensitivity to $\beta$-adrenoceptor agonists of adipocytes from rats treated with an aqueous extract of Croton cajucara Benth. J. Pharm. Pharmacol. 55, 253-257.

Grynberg, N.F., Echevarria, A., Lima, J.E., Pamplona, S.S.R., Pinto, A.C., Maciel, M.A.M., 1999. Anti-tumour activity of two 19-nor-clerodane diterpenes, transdehydrocrotonin and trans-crotonin, from Croton cajucara. Planta Med. 65, 687-689.

Hall, T.A., 1999. BioEdit: a user-friendly biological sequence alignment editor and analysis program for Windows 95/98/NT. Nucl. Acids Symp. Ser. 41, 95-98.

Hiruma-Lima, C.A., Gracioso, J.S., Nunes, D.S., Souza Brito, A.R.M., 1999a. Effects of an essential oil from the bark of Croton cajucara Benth. on experimental gastric ulcer models in rats and mice. J. Pharm. Pharmacol. 51, 341-346.

Hiruma-Lima, C.A., Spadari-Bratfisch, R.C., Grassi-Kassisse, D.M., Souza-Brito, A.R.M., 1999b. Antiulcerogenic mechanisms of deydrocrotonin, a diterpene lactone obtained from Croton cajucara. Planta Med. 65, 325-330.

Hiruma-Lima, C.A., Gracioso, J.S., Bighetti, E.J., Grassi-Kassisse, D.M., Nunes, D.S., Brito, A.R., 2002. Effect of essential oil obtained from Croton cajucara Benth. on gastric ulcer healing and protective factors of the gastric mucosa. Phytomedicine 9, 523-529.

Huelsenbeck, J.P., Ronquist, F., 2001. MrBayes: Bayesian inference of phylogeny. Bioinformatics 17, 754-755.

Kress, W.J., Wurdack, K.J., Zimmer, E.A., Weigt, L.A., Janzen, D.H., 2005. Use of DNA barcodes to identify flowering plants. Proc. Natl. Acad. Sci. USA 102, 83698374.

Lahaye, R., van der Bank, M., Bogarin, D., Wagner, J., Pupulin, F., Gigot, G., Maurin, O. Duthoit, S., Barraclough, T.G., Savolainen, V., 2008. DNA barcoding the floras of biodiversity hotspots. Proc. Natl. Acad. Sci. USA 105, 2923-2928.

Le Cointe, P., 1934. Árvores e plantas úteis (indígenas e aclimatadas). Série: A Amazônia Brasileira, n 3. Livraria Clássica, Belém.

Lemos, T.L.G., Machado, M.I.L., Menezes, J.E.S.A., Sousa, C.R., 1999. Essential oil of Croton cajucara Benth. J. Essent. Oil Res. 11, 411-412.

Lima, L.R., Pirani, J.R., 2008. Revisão taxonômica de Croton sect. Lamprocroton (Müll.Arg.) Pax (Euphorbiaceae s.s.). Biota Neotrop. 8, 21-75

Lopes, D., Bizzo, H.R., Sa-Sobrinho, A.F., Pereira, M.V.G., 2000. Linalool-rich essential oil from leaves of Croton cajucara Benth. J. Essent. Oil Res. 12, 705-708.

Maciel, M.A.M., Pinto, A.C., Brabo, S.N., Arruda, A.C., 1998a. Estudo da variação dos teores de terpenóides bioativos isolados das cascas de Croton cajucara, nativos e cultivados no estado do Pará. Rev. Univers. Rural 20,17-34.

Maciel, M.A.M., Pinto, A.C., Brabo, S.N., Da Silva, M.N., 1998b. Terpenoids from Croton cajucara. Phytochemistry 49, 823-828.

Maciel, M.A.M., Pinto, A.C., Arruda, A.C., Pamplona, S.G.S.R., Vanderlinde, F.A., Lapa, A.J., Echevarria, A., Grynberg, N.F., Côlus, I.M.S., Farias, R.A.F., Costa, A.M.L., Rao, V.S.N., 2000. Ethnopharmacology, phytochemistry and pharmacology: a successful combination in the study of Croton cajucara. J. Ethnopharmacol. 70, 41-55.

Maciel, M.A.M., Pinto, A.C., Veiga Jr., V.F., Martins, J.R., Grynberg, N.F., Echevarria, A., Lapa, A.J., Vanderlinde, F.A., 2002. Croton cajucara as an alternative to traditional medicine in a modern health system. Recent Prog. Med. Plant 8, 502-517.

Maddison, W.P., Maddison, D.R., 2009. Mesquite: A Modular System for Evolutionary Analysis. Version 2.72. <http://mesquiteproject.org>

Moreno, P.R., Lima, M.E.L., Caruzo, M.B.R., Torres, D.S.C., Cordeiro, I., Young, M.C.M., 2009. Chemical composition and antimicrobial activity of the essential oil from Croton heterocalyx Baill. (Euphorbiaceae s.s.) leaves. J. Essent. Oil Res. 21, 190192

Müller, J., 1873. Euphorbiaceae. In: Martius, C.F.P., Eichler, A.G. (Eds.), Flora Brasiliensis, vol. 11, no. 2, pp. 1-752 (pl. 43-104).

Pennington, R.T., Lewis, G.P., Ratter, J.A., 2006. An overview of the plant diversity, biogeography and conservation of Neotropical savannas and seasonally dry forests. In: Pennington, R.T., Lewis, G.P., Ratter, J.A. (Eds.), Neotropical savannas and dry forests: diversity, biogeography, and conservation. Systematics association special volume no. 69. CRC Press, Boca Raton, pp. 1-29.

Perazzo, F.F., Carvalho, J.C.T., Rodrigues, M., Morais, E.K.L., Maciel, M.A.M., 2007. Comparative anti-inflammatory and antinociceptive effects of terpenoids and an aqueous extract obtained from Croton cajucara Benth. Rev. Bras. Farmacogn. $17,521-528$.

Prado, D.E., 2000. Seasonally dry forests of tropical South America: from forgotten ecosystems to a new phytogeographic unit. Edinburgh J. Bot 57 (3), 437-461.

Riina, R., Berry, P.E., Van Ee, B.W., 2009. Molecular phylogenetics of the dragon's blood Croton section Cyclostigma (Euphorbiaceae): a polyphyletic assemblage unraveled. Syst. Bot. 34, 360-374.

Riina, R., Van Ee, B.W., Wiedenhoeft, A.C., Cardozo, A., Berry, P.E., 2010. Sectional rearrangement of arborescent clades of Croton (Euphorbiaceae) in South America: evolution of arillate seeds and a new species, Croton domatifer. Taxon 59, 1147-1160. 
206

Maria Beatriz R. Caruzo et al./Molecular Phylogenetics and Evolution 60 (2011) 193-206

Rosa, M.D.S., Mendonca, R.R., Bizzo, H.R., Rodrigues, I.D., Soares, R.M.A., SoutoPadron, T., Alviano, C.S., Lopes, A.H.C.S., 2003. Antileishmanial activity of a linalool-rich essential oil from Croton cajucara. Antimicrob. Agents Chemother 47, 1895-1901.

Salatino, A., Salatino, M.L.F., Negri, G., 2007. Traditional uses, chemistry and pharmacology of Croton species (Euphorbiaceae). J. Braz. Chem. Soc. 18, 1133.

Sang, T., Crawford, D.J., Stuessy, T.F., 1997. Chloroplast DNA phylogeny, reticulate evolution, and biogeography of Paeonia (Paeoniaceae). Am. J. Bot. 84, 1120 1136.

Santos, F.V., Mesquita, S.F.P., Faria, M.J.S.S., Poersh, A., Maciel, M.A.M., Pinto, A.C., Morimoto, H.K., Cólus, I.M.S., 2006. Absence of mutagenicity in stomatic and germ cells of mice submitted to subchronic treatment with an extract of Croton cajucara Benth. (Euphorbiaceae). Genet. Mol. Biol. 29, 159-165.

Silva, R.M., Santos, F.A., Maciel, M.A.M., Pinto, A.C., Rao, V.S., 2001a. Effect of transdehydrocrotonin, a 19-nor-clerodane diterpene from Croton cajucara on experimental hypertriglyceridaemia and hypercholesterolaemis induced by Triton WR 1339 (tyloxapol) in mice. Planta Med. 67, 763-765.

Silva, R.M., Santos, F.A., Rao, V.S.N., Maciel, M.A.M., Pinto, A.C., 2001b. The lipidlowering effect of trans-dehydrocrotonin from Croton cajucara Benth. in mice fed on high-fat diet. J. Pharm. Pharmacol. 53, 535-539.

Souza, M.A.A., Souza, S.R., Veiga Jr., V.F., Cortez, JK.P.C., Leal, R.S., Dantas, T.N.C., Maciel, M.A.M., 2006. Composição química do óleo fixo de Croton cajucara e determinação das suas propriedades fungicidas. Rev. Bras. Farmacogn. 16, 599610.

Souza-Brito, A.R.M., Rodríguez, J.A., Hiruma-Lima, C.A., Haun, M., Nunes, D.C., 1998 Antiulcerogenic activity of trans-dehydrocrotonin from Croton cajucara. Planta Med. 64, 126-129.
Staden, R., 1996. The Staden sequence analysis package. Mol. Biotechnol. 5, 233241. <http://staden.sourceforge.net/>.

Swofford, D.L., 2002. PAUP* Phylogenetic Analysis Using Parsimony (*and Other Methods), Version 4.0b10. Sinauer Associates, Sunderland.

Tamura, K., Dudley, J., Nei, M., Kumar, S., 2007. MEGA 4: Molecular Evolutionary Genetics Analysis (MEGA) Software Version 4.0. Mol. Biol. Evol. 24, 1596-1599.

Tate, J.A., Simpson, B.B., 2003. Paraphyly of Tarasa (Malvaceae) and diverse origins of the polyploid species. Syst. Bot. 28, 723-737.

Thompson, J.D., Gibson, T.J., Plewniak, F., Jeanmougin, F., Higgins, D.G., 1997. The Clustal X windows interface. Flexible strategies for multiple sequence alignment aided by quality analysis tools. Nucl. Acids Res. 25, 4876-4882.

Van Ee, B.W., Riina, R., Berry, P.E., in press. A revised synopsis and molecular phylogeny of the New World sections of Croton (Euphorbiaceae). Taxon, 60.

Van Ee, B.W., Berry, P.E., Riina, R., Gutiérrez Amaro, J.E., 2008. Molecular phylogenetics and biogeography of the Caribbean-centered Croton subgenus Moacroton (Euphorbiaceae s.s.). Bot. Rev. 74, 132-165.

Van Ee, B.W., Berry, P.E., 2009. A phylogenetic and taxonomic review of Croton (Euphorbiaceae s.s.) on Jamaica including the description of Croton jamaicensis, a new species of section Eluteria. Syst. Bot. 34, 129-140.

Van Ee, B.W., Berry, P.E., 2010. Taxonomy and phylogeny of Croton section Heptallon (Euphorbiaceae). Syst. Bot. 35, 151-167.

Van Ee, B.W., Berry, P.E., 2011. Croton section Pedicellati (Euphorbiaceae), a novel new world group, and a new subsectional classification of Croton section Lamprocroton. Syst. Bot. 36, 88-98.

Webster, G.L., 1993. A provisional synopsis of the sections of the genus Croton L. (Euphorbiaceae). Taxon 42, 793-823.

Webster, G.L., Del-Arco-Aguilar, M.J., Smith, B.A., 1996. Systematic distribution of foliar trichome types in Croton (Euphorbiaceae). Bot. J. Linn. Soc. 121, 41-57. 